\title{
Listening to the Patient
}

\author{
Denis Daneman* \\ Department of Paediatrics, University of Toronto, Canada
}

Submission: February 09, 2018; Published: February 22, 2018

*Corresponding author: Denis Daneman, Chair Emeritus, Department of Paediatrics, University of Toronto, Paediatrician-in-Chief Emeritus, The Hospital for Sick Children, Toronto, Canada, Email: Denis.daneman@sickkids.ca

\section{Opinion}

One of the first medical books I read about diabetes in childhood and adolescence was by Oman Craig, a physician from Glasgow, Scotland (Craig O. Childhood Diabetes: The Facts). In the dedication of the book he wrote: "Talking to a doubting parent is like flamenco dancing in a bath of mud." This is highly evocative, conjuring up a vision of an emphatic and ever increasing splattering mess (see attached cartoon).My initial response to this comment was one of amusement. This was quickly followed by a simple question: Who is making the mess, the parent or the health care professional doing the talking? My experiences over the next almost 40 years have persuaded me that it is indeed both. And this is exactly the situation we all wish to avoid if we are to help our patients achieve the ever-tightening goals of diabetes care: based on solid research, the better the control as measured by A1c levels, the less the risk for onset or progression of diabetes-related micro- and macrovascular complications. Simple as that, but not so simple (Figure 1).

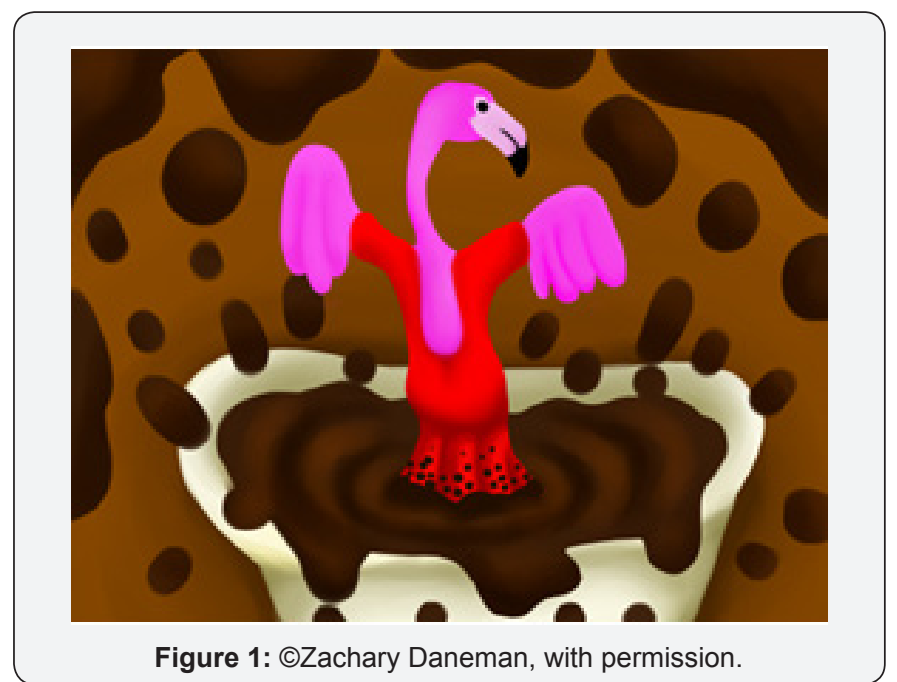

The pathway to protection is increasingly well laid out in clinical practice guidelines: "pragmatic approaches to therapy to achieve dogmatic goals," is the neat way my colleague, Fergus Cameron, from Melbourne, Australia, has put it. In other words, do what it takes, and, absent an artificial or biological pancreas alternative, this means put the increasingly sophisticated and available technology to best use to achieve the best outcomes: insulin analogues, insulin pumps, sensors. But, and there are many buts, we give insulin in the wrong place (subcutaneous rather than intraportal) at the wrong dose at the wrong time, and we still depend on the human brain to make decisions that ought to be made by the beta cells' exquisite GLUT2-glucokinase sensing system. And yet we are surprised that all of our patients do not have A1cs in target and most especially the biggest at risk group -TEENS!

Let me suggest a good way to think about it for a moment: think about this as a three step process:

\section{A. The first A: ATTACHMENT}

B. Then Daniel Pink's ABC from his book "To Sell is Human:" A is ATTUNEMENT, B is for BOUYANCY and C for CLARITY

C. Finally, the two most underrated of human activities: LISTENING and WATCHING (the patient)

Too often we teach the teen and family what they need to do (WE KNOW BEST, after all!), how to do it and who to call when in trouble. But don't we need to pay more attention to how this information is received and applied? Pink suggests that we are all salespeople, in the case of diabetes care, the product we are selling is "the pathway to maintaining good health." From the patient/family standpoint this requires a secure attachment style with their health professionals (Patient: Am I worthy of their attention, and can I trust them: If YES/YES then it's a secure style, if YES/No, often dismissive, and if NO/yes or no then fearful or avoidant, respectively).From the health care professionals' standpoint, having a sense of where the patient is located, helps to adjust our approach to theirs.

If the attachment styles are at odds, attunement is impossible, and attunement (are we on the same page, or are our goals the 


\section{Current Research in Diabetes \& Obesity Journal}

same?) is step 1 to success. Bouyancy or enthusiasm and clarity or simplicity follow attunement as the next essentials.

Finally, Sir Alec Ferguson, the iconic manager of the Manchester United football team for over 20 years, observed that the two most underrated of human activities are listening and watching. In diabetes care, this means carefully listening to the patient's comments and watching their body language.
By doing this we learn a huge amount of what it is our patients need, not just what we want them to do. These two things are often at odds and it is our formidable role to get them attuned.

This is an opinion piece, and my opinion is strongly stated. What these opinions need now is a firm scientific footing and interventions that optimize conditions which stand in the way of achieving targets. There are many careers in these endeavours.

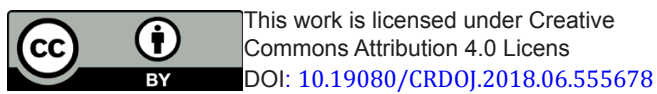

\begin{tabular}{l} 
Your next submission with Juniper Publishers \\
will reach you the below assets \\
- Quality Editorial service \\
- Swift Peer Review \\
- Reprints availability \\
- E-prints Service \\
- Manuscript Podcast for convenient understanding \\
- Global attainment for your research \\
- Manuscript accessibility in different formats \\
( Pdf, E-pub, Full Text, Audio) \\
- Unceasing customer service \\
Track the below URL for one-step submission \\
https://juniperpublishers.com/online-submission.php \\
\hline
\end{tabular}

